УДК 330.31.43.2

DOI: $10.15673 /$ fie.v12i3.1818

\author{
Нікішина О.В. \\ доктор економічних наук, старший науковий співробітник \\ завідувач відділу ринкових механізмів та структур \\ Інститут проблем ринку та економіко-екологічних досліджень НАН України \\ Французький бульвар, 29, м. Одеса, Україна, 65044 \\ E-mail: ksenkych@gmail.com \\ ORCID ID: 0000-0002-7172-3551
}

\title{
ТЕОРЕТИКО-МЕТОДИЧНІ ПОЛОЖЕННЯ ЩОДО КОМПЛЕКСНОЇ ОЦІНКИ ДОМІНАНТ ІНВЕСТИЦІЙНО-ІННОВАЦІЙНОЇ ПОЛІТИКИ ПРИРОДОКОРИСТУВАННЯ УКРАЇНИ*
}

Стаття присвячена обґрунтуванню теоретико-методичного забезпечення комплексної оцінки домінант інвестиційно-інноваційної політики природокористування національної економіки на засадах концепцій сталого розвитку та інноваційної «квадро-спіралі». Вдосконалено понятійно-категоріальний апарат дослідження, розроблено методологічний підхід до комплексної оцінки домінант політики. Визначено домінанти (стратегічні пріоритети) інвестиційно-інноваційної політики природокористування та відповідні їм групи оціночних індикаторів. Обґрунтовано мету, принципи та методичні положення щодо комплексної оцінки домінант політики з акцентом на секторально-структурний вимір. На основі розробленого методичного забезпечення здійснено діагностику трьох домінант політики природокористування, пов'язаних 3 використанням інвестиційно-інноваційного потенціалу України, визначено сучасні тренди та проблеми його використання. На підставі результатів якісної оцінки окреслено напрями модернізації механізмів стимулювання раціонального природокористування в державі.

Ключові слова: природокористування, оцінка, індикатори, сталий розвиток, інвестиційноінноваційна політика, інвестиції, сектори економіки.

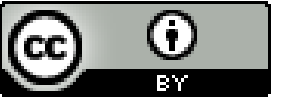

This work is licensed under a Creative Commons Attribution 4.0 International License http://creativecommons.org/licenses/by/4.0/
Постановка проблеми та їі зв'язок з важливими науковими та практичними завданнями. В умовах посилення дестабілізуючого впливу економічної діяльності суспільства на стан навколишнього природного середовища (далі - НПС), активізації погроз екологічній безпеці України, неефективного використання іiі природно-ресурсного потенціалу виникає необхідність в реалізації сучасної моделі інвестиційно-інноваційної політики природокористування (далі - ІІПП). Її основу формує, з одного боку, система партнерства між державою, наукою, бізнесом та суспільством на засадах впровадження концепції «квадро-спіралі», з іншого, сталий, екологічно збалансований розвиток. Актуальність обраної теми обумовлена необхідністю розробки теоретикометодичного базису формування ІІПП, тому що це підгрунтя $\epsilon$ науковою основою для впровадження адаптивних механізмів стимулювання раціонального природокористування національної економіки.

Проблематика дослідження тісно пов'язана 3 інститутами сталого розвитку, зокрема, програмою впровадження Цілей сталого розвитку до 2030 р., проголошених резолюцією Генеральної Асамблеї
ООН № 70/1 від 25.09.2015 р. [1], Стратегією сталого розвитку України до 2030 р. [2], Указом Президента України №722/2019 від 30.09.2019 р. [3].

Аналіз останніх публікацій по проблемі. В науці існує певний доробок щодо методологічного забезпечення екологізації ІІПП. Так, методичні підходи до оцінки «зеленої» трансформації на основі показників «зеленого» зростання ОЕСР запропоновані Л. Мусіною та Т. Квашою [4]. Методологічні засади моніторингу ЦСР в Україні викладені в Національній доповіді Міністерства економічного розвитку і торгівлі України [5]. Методичні підходи щодо визначення домінант ІІПП в регіональному вимірі розроблені Андрєєвою Н.М. та Тютюнник Г.О. [6], методичні рекомендації до оцінки впливу економічних показників на головні індикатори «зеленої» зростання Буркинським Б.В. та ін. вченими [7]. Перелічені методичні підходи дозволяють багатоаспектно оцінити різні грані ІІПП, водночас відсутнє комплексне методичне забезпечення діагностики домінант (пріоритетів) даної політики на засадах сталого розвитку та концепції «квадро-спіралі». Дану концепцію розробили Караянніс Е.Г., Барт Т.Д. та Д.ФДж.Кемпбелл,

* Публікацію підготовлено в межах НДР «Домінанти інвестиційно-інноваційної політики природокористування національної економіки» за рахунок коштів бюджетної програми «Підтримка розвитку пріоритетних напрямів наукових досліджень» (КПКВК 6541230). 
розширивши традиційну потрійну інноваційну спіраль шляхом включення до іiї складу суспільства та різних стейколдерів [8]. Сучасні трансформації концептуального базису передбачають нововведення в методології оцінки ІІПП.

Формулювання цілей дослідження. Мета статті - розробка теоретико- методичного базису комплексної оцінки домінант ІІПП та здійснення на його основі діагностики сучасних тенденцій і проблем інвестиційно-інноваційного забезпечення раціонального природокористування в Україні з акцентом на секторально-структурний вимір та сталий розвиток національної економіки.

Виклад основних результатів та їх обгрунтування. Понятійно-категоріальний апарат дослідження формують категорії домінанта, ІІПП, інвестиційно-інноваційний та природно-ресурсний потенціал. Домінанта (від лат. dominans - панівний) - це стратегічний пріоритет, який, з одного боку, учені трактують як «вид ієрархії, коли певним цілям надають перевагу порівняно з іншими цілями» [9, с. 411], 3 іншого, як «щось переважаюче, найголовніше, перевага у певному відкритті, напрямі тощо» [10, с. 90]. У даному дослідженні під домінантами ІІПП ми будемо розуміти головні цілі (стратегічні пріоритети) політики інвестиційно-інноваційного забезпечення сфери раціонального природокористування та екологічної безпеки держави на засадах сталого розвитку. У політології наявні два підходи до визначення змісту категорії «політика»: (1) традиційний, пов'язаний 3 діяльністю держави; (2) новий, як певний вид соціальної діяльності, не обов'язково поєднаної з державною владою (таблиця 1). Враховуючи, що суб'єктами IIIП виступають не тільки держава, але й суспільство та різні стейколдери, у даному дослідженні застосуємо другий підхід, який отримав поширення в європейських країнах.

Таблиця 1

Категорійна сукупність визначення сутності поняття «інвестиційно-інноваційна політика природокористування» "

\begin{tabular}{|l|l|}
\hline \multicolumn{1}{|c|}{ Політика } & $\begin{array}{l}\text { Діяльність класів, соціальних верств, груп та індивідів, пов’язана з визначенням і впли- } \\
\text { вом на устрій державної влади, (у т. ч. функції та форми держави), а також на відносини } \\
\text { 3 іншими класами, націями, країнами з метою реалізації власних інтересів [11]. } \\
\text { Вид соціальної діяльності; спосіб упорядкування суспільних справ, що стосуються, пе- } \\
\text { редусім, розподілу обмежених ресурсів, принципів, за якими він здійснюється, засобів, } \\
\text { завдяки яким соціальні спільноти вирішують різні проблеми [13] }\end{array}$ \\
\hline $\begin{array}{l}\text { Екологічна } \\
\text { політика }\end{array}$ & $\begin{array}{l}\text { Свідома і організована регулююча діяльність, за допомогою якої та за посередництва } \\
\text { держави і громадських, чи політичних організацій, регулюються ставлення суспільства } \\
\text { до природи з метою захисту і розвитку довкілля [11]. }\end{array}$ \\
\hline $\begin{array}{l}\text { Інвестиційна } \\
\text { політика }\end{array}$ & $\begin{array}{l}\text { Комплекс урядових рішень, які визначають основні напрямки, джерела та обсяги вико- } \\
\text { ристання капітальних вкладень в економіку, різні ії сфери та галузі [12]. }\end{array}$ \\
\hline $\begin{array}{l}\text { Інвестиційно- } \\
\text { інноваційна } \\
\text { політика приро- } \\
\text { до-користування }\end{array}$ & $\begin{array}{l}\text { Діяльність державних та регіональних органів, спрямована на створення сприятливих } \\
\text { інституціональних та економічних умов щодо стимулювання процесу впровадження } \\
\text { екологічно орієнтованих інвестицій та інновацій у господарську діяльність суб’єктів } 3 \\
\text { урахуванням наявного природно-ресурсного потенціалу [6]. }\end{array}$ \\
\hline $\begin{array}{l}\text { Інвестиційно- } \\
\text { інноваційна } \\
\text { політика приро- } \\
\text { до-користування }\end{array}$ & $\begin{array}{l}\text { Сукупність економічних, організаційних та інституційних заходів, механізмів, методів } \\
\text { та форм управління екологічно орієнтованими інвестиціями та інноваціями для сталого } \\
\text { використання, відтворення й охорони складових природно-ресурсного потенціалу, які } \\
\text { реалізуються державними органами влади, представниками бізнесу, науки та різних } \\
\text { стейкхолдерів на засадах сталого розвитку національної економіки (авт.) }\end{array}$ \\
\hline
\end{tabular}
*сформовано автором на основі джерел $[6,10,11,12]$

Енциклопедичні ресурси не надають визначення категорії «інвестиційно-інноваційна політика природокористування», наявні лише окремі трактування дефініцій «екологічна» та «інвестиційна політика» (див. табл. 1). Найбільш глибоким є трактування вихідної категорії, представленої у праці [6], однак автори сфокусували увагу на державній діяльності, залишивши поза увагою питання інвестиційної діяльності стейкхолдерів та сталого розвитку. Врахувавши існуючі дефініції, запропоновано наступне авторське визначення категорії «інвестиційно-інноваційна політика природокористування»: сукупність економічних, організаційних та інституційних заходів, механізмів, методів та форм управління екологічно орієнтованими інвестиціями та інноваціями для сталого використання, відтворення й охорони складових природно-ресурсного потенціалу, які реалізуються державними органами влади, представниками бізнесу, науки та різних стейкхолдерів на засадах сталого розвитку національної економіки. У даному визначенні акцент зміщено на взаємодію чотирьох суб'єктів ІІПП крізь призму концепцій «квадро-спіралі» та сталого розвитку економіки.

Найбільш точне і вичерпне визначення терміну «потенціал», на наш погляд, запропонував С.В. Мочерний: «наявні ресурси, їх оптимальна структура та вміння раціонально використати їх для досягнення поставленої мети» [10, с.13]. Дане визначення з уточненням виду ресурсів (інвестиційні, природні) можна використати для розкриття змісту інвестиційноінноваційного та природно-ресурсного потенціалів. Такі компоненти потенціалу, як оптимальна структура та раціональне використання ресурсів, формують напрями і завдання їх комплексної оцінки, як підгрунтя для управлінських рішень різних суб'єктів ІІПП та їх взаємодій. 
Методичні положення щодо комплексної оцінки домінант ІІПП базуються на тезі, що кожна домінанта ІІПП потребує введення відповідних їй індикаторів оцінки. Тобто сукупність домінант ІІПП можна представити у вигляді системи економікоекологічних індикаторів, оцінка яких дозволяє визначити основні тенденції в природокористуванні, причинно-наслідкові зв'язки зміни стану природного середовища, ефективність чинної екологічної політики та напрями іiі трансформації. Головні домінанти ІІПП та відповідні їм групи індикаторів представлено на рис. 1. Було виокремлено шість домінант (страте- гічних пріоритетів) ІІПП, орієнтованих на інвестиційне забезпечення раціонального природокористування, стале використання компонентів природноресурсного потенціалу країни, зниження екодеструктивного впливу соціально-економічної системи на стан НПС, підвищення екологічних аспектів якості життя населення. Для комплексної оцінки перелічених домінант ІІПП запропоновано використати множину індикаторів, об'єднаних у вісім груп. Інформаційною базою для їх розрахунку є офіційні дані Державної служби статистики України, дані міністерств та відомств, державних і профільних інституцій.

\begin{tabular}{|c|c|}
\hline \multicolumn{2}{|c|}{$\begin{array}{c}\text { Концептуальний базис: концепції сталого розвитку, «зеленого» зростання, циркулярної економіки, іннова- } \\
\text { ційного розвитку на основі «квадро-спіралі» }\end{array}$} \\
\hline \multicolumn{2}{|c|}{$\begin{array}{l}\text { Мета методичних положень: комплексна оцінка ефективності діючої ІІПП, визначення недоліків і пробле- } \\
\text { мних місць у процесі ï впровадження, обгрунтування домінант ІІПП та адаптивних механізмів їх впрова- } \\
\text { дження в сучасних умовах }\end{array}$} \\
\hline \multicolumn{2}{|c|}{$\begin{array}{l}\text { Принципи оцінки: системність і комплексність; адекватність і гнучкість; об’єктивність і точність; дієвість; } \\
\text { цілеспрямованість; науковість }\end{array}$} \\
\hline \multicolumn{2}{|c|}{$\begin{array}{l}\text { Методичні положення щодо комплексної оцінки домінант IIПП: Етапи оцінки: } \\
\text { І. Комплексна оцінка впровадження домінант ІІПП за допомогою груп індикаторів: }\end{array}$} \\
\hline Іти ІІПП & Групи оціночних \\
\hline $\begin{array}{l}\text { 1. Достатнє інвестиційнє } \\
\text { ного природокористуван }\end{array}$ & $\begin{array}{l}\text { 1. Частка екологічних інвестиц } \\
\text { бюджету на охорону НПС }\end{array}$ \\
\hline $\begin{array}{l}\text { 2. Оптимальний перерозподіл інвестиційних ресур- } \\
\text { сів між видами природоохоронних заходів та сек- } \\
\text { торами національної економіки }\end{array}$ & $\begin{array}{l}\text { 2. Оцінка динамічних та структурних змін капітальних } \\
\text { та поточних інвестицій на охорону НПС } \\
\text { 3. Оцінка динамічних змін сукупних витрат на охорону } \\
\text { НПС }\end{array}$ \\
\hline $\begin{array}{l}\text { Іного забе } \\
\text { оодокорис }\end{array}$ & $\begin{array}{l}\text { 4. Оцін } \\
\text { ру екон }\end{array}$ \\
\hline $\begin{array}{l}\text { 4. Відновлення, стале використання та охорона } \\
\text { складових природно-ресурсного потенціалу націо- } \\
\text { нальної економіки }\end{array}$ & $\begin{array}{l}\text { 5. Оцінка використання водних, енергетичних, земель- } \\
\text { них, лісових, мінерально-сировинних ресурсів, приро- } \\
\text { дно-заповідного фонду в координатах сталого розвит- } \\
\text { ку }\end{array}$ \\
\hline $\begin{array}{l}\text { оого впливу } \\
\text { н НПС }\end{array}$ & $\begin{array}{l}\text { 6. Оцінка екологічної ємю } \\
\text { розвитку }\end{array}$ \\
\hline $\begin{array}{l}\text { 6.Підвищення екологічних аспектів якості життя } \\
\text { населення }\end{array}$ & $\begin{array}{l}\text { 7. Оцінка трудових ресурсів сфери природокористу- } \\
\text { вання } \\
\text { 8.Оцінка екологічних аспектів якості життя населення }\end{array}$ \\
\hline \multicolumn{2}{|c|}{$\begin{array}{l}\text { II. Оцінка відхилень фактичних значень індикаторів від цільових та світових значень } \\
\text { III. Визначення причин відхилень, причинно-наслідкових зв’язків між економіко-екологічними індикатора- } \\
\text { ми, проблемних аспектів впровадження діючої ІІПП } \\
\text { IV. Якісна оцінка індикаторів, агрегований висновок про стан досягнення домінант ІППП }\end{array}$} \\
\hline $\begin{array}{l}\text { Механізми стимулювання впровадження еколог } \\
\text { суб'єктів господарюван } \\
\text { 1. Інституціональні; } \\
\text { 2. Фінансово-економічні; }\end{array}$ & $\begin{array}{l}\text { Іно орієнтованих інвестицій та інновацій у діяльність } \\
\text { різних секторів економіки: } \\
\text {. Адміністративні; } \\
\text {.Інформаційні. }\end{array}$ \\
\hline
\end{tabular}

Рис. 1. Структурна схема методологічного підходу до комплексної оцінки домінант інвестиційно-інноваційної політики природокористування* *авторська розробка

Методичні положення щодо комплексної оцінки домінант ІІПП включають п’ять етапів оцінки (див. рис. 1). Результати такої оцінки формують аналітичне підгрунтя для визначення ефективності політики, обгрунтування механізмів стимулювання екологічно орієнтованих інвестицій та інновацій у вітчиз- няну практику господарювання. Особливістю методичних положень є, по-перше, секторальний вимір індикаторів для встановлення тенденцій і проблем природокористування в секторальному вимірі, подруге, оцінка домінант крізь призму сталого розвитку, що дозволяє зробити висновок не тільки про ефе- 
ктивність ІІПП, а й стратегії сталого розвитку в Україні. Дана стаття присвячена комплексній оцінці перших трьох домінант ІІПП (див. рис. 1), пов'язаних 3 використанням інвестиційно-інноваційного потенціалу.

За статистичними даними, у 2019 р. величина загальних капітальних інвестицій усіх секторів національної економіки склала 584,5 млрд. грн., збільшившись порівняно 32010 р. втричі (таблиця 2). При цьому їх величина у ВВП країни скоротилася з 17,5\% в 2010 р. до 14,7 \% в 2019 р. У 2018 р. обсяг капітальних інвестицій на охорону НПС досяг 10,07 млрд. грн., що склало всього 1,74 \% від загального обсягу капітальних інвестицій в економіку та $0,28 \%$ від ВВП. Починаючи 32017 р. відбувається зменшення частки капітальних інвестицій на охорону НПС у ВВП держави, при цьому індикатор 2019 р. складає $0,23 \%$, що менше рівня 2010 р.

Таблиця 2

Динаміка капітальних інвестицій (КI) на охорону НПС в Україні та їх частка у ВВП*

\begin{tabular}{|c|c|c|c|c|c|c|c|c|c|}
\hline \multirow{2}{*}{ Показники } & \multicolumn{8}{|c|}{ Роки } & \multirow{2}{*}{$\begin{array}{l}2019 p . \\
\text { y \% до } \\
2010 \text { p. }\end{array}$} \\
\hline & 2010 & 2013 & 2014 & 2015 & 2016 & 2017 & 2018 & 2019 & \\
\hline $\begin{array}{l}\text { 1. Капітальні інвести- } \\
\text { ції, всього, млрд. грн. }\end{array}$ & 189,06 & 267,73 & 219,42 & 273,12 & 359,22 & 448,46 & 578,73 & 584,45 & 309,1 \\
\hline $\begin{array}{l}\text { 2. Частка загальних КІ } \\
\text { у ВВП, \% }\end{array}$ & 17,5 & 18,3 & 13,8 & 13,7 & 15,1 & 15,0 & 16,3 & 14,7 & $-2,81$ \\
\hline $\begin{array}{l}\text { 3.Капітальні інвести- } \\
\text { ції на охорону НПС, } \\
\text { млн. грн. }\end{array}$ & 2761,5 & 6038,8 & 7959,9 & 7676,6 & 13390,5 & 11026 & 10074 & $9167,6^{* *}$ & 332,0 \\
\hline $\begin{array}{l}\text { 4. Частка КІ на охо- } \\
\text { рону НПС у\% до за- } \\
\text { гальних капітальних } \\
\text { інвестицій, \% }\end{array}$ & 1,46 & 2,26 & 3,63 & 2,81 & 3,73 & 2,46 & 1,74 & 1,57 & $+0,11$ \\
\hline $\begin{array}{l}\text { 5. Частка КІ на охо- } \\
\text { рону НПС у ВВП, \% }\end{array}$ & 0,26 & 0,41 & 0,50 & 0,39 & 0,56 & 0,37 & 0,28 & 0,23 & $-0,03$ \\
\hline
\end{tabular}

"розраховано автором за даними Державної служби статистики України $[14,15,16]$. ** попередні дані. скорочення: KI - капітальні інвестиції.

Сукупні витрати на охорону НПС, які поєднують капітальні інвестиції та поточні витрати, в 2018 р. склали 34,39 млрд. грн., збільшившись порівняно 32010 р. у 2,6 рази (таблиця 3). При цьому темп приросту капітальних інвестицій (3,6 рази) є нижчим аналогічного показника для поточних витрат $(2,3 \%)$. За досліджуваний період частка сукупних витрат на охорону НПС в Україні скоротилася $31,22 \%$ в 2010 р. до $0,97 \%$ в 2018 р., при цьому найвищі рівні індикатора спостерігалися в 2013-2014 pp. (1,39-
$1,38 \%)$. У розвинутих країнах частка сукупних витрат на охорону НПС складає 1,5-4\% ВВП, що визначається досягнутим ступенем якості навколишнього природного середовища [17, с.182]. За 2010-2018 рр. фактичний рівень індикатора в Україні не потрапив у коридор оптимальних значень (див. табл. 3). Слід зазначити, що в 1995-2005 рр. частка сукупних витрат на охорону НПС в нашій державі була значно вищою $(5,1-1,6 \%)$ і відповідала світовому рівню.

Динамічно-структурні зміни сукупних витрат на охорону НПС в Україні та бюджетні видатки *

\begin{tabular}{|c|c|c|c|c|c|c|c|c|}
\hline \multirow{2}{*}{ Показники } & \multicolumn{7}{|c|}{ Роки } & \multirow{2}{*}{$\begin{array}{l}2018 \mathrm{p} . \\
\text { у \% до } \\
2010 \mathrm{p} .\end{array}$} \\
\hline & 2010 & 2013 & 2014 & 2015 & 2016 & 2017 & 2018 & \\
\hline $\begin{array}{l}\text { 1. Сукупні витрати на охоро- } \\
\text { ну навколишнього природно- } \\
\text { го середовища (у фактичних } \\
\text { цінах), млн. грн. }\end{array}$ & 13128,1 & 20377,9 & 21925,6 & 24591,1 & 32488,7 & 31492 & 34392,3 & 261,97 \\
\hline Індекс, пункти & $X$ & 0,993 & 1,076 & 1,122 & 1,321 & 0,969 & 1,092 & $\mathrm{X}$ \\
\hline $\begin{array}{l}\text { 2. Капітальні інвестиції й } \\
\text { поточні витрати, у \% до } \\
\text { ВВП у фактичних цінах }\end{array}$ & 1,22 & 1,39 & 1,38 & 1,24 & 1,36 & 1,06 & $\mathbf{0 , 9 7}$ & $\mathbf{X}$ \\
\hline 3. Капітальні інвестиції & 2761,5 & 6038,8 & 7959,9 & 7675,6 & 13390,5 & 11025,6 & 10074,3 & 364,81 \\
\hline у \% до сукупних витрат & 21,04 & 29,63 & 36,30 & 31,21 & 41,22 & 35,01 & 29,29 & $\mathrm{X}$ \\
\hline 4. Поточні витрати & 10366,6 & 14339,1 & 13965,7 & 16915,5 & 19098,2 & 20466,4 & 24318 & 234,58 \\
\hline у \% до сукупних витрат & 78,96 & 70,37 & 63,70 & 68,79 & 58,78 & 64,99 & 70,71 & X \\
\hline
\end{tabular}


Продовження табл. 3

\begin{tabular}{|l|c|c|c|c|c|c|c|c|}
\hline \multicolumn{1}{|c|}{ Показники } & \multicolumn{7}{|c|}{ Роки } & $\begin{array}{l}2018 \text { р. } \\
\text { у \% до } \\
2010 \text { p. }\end{array}$ \\
\cline { 2 - 10 } & 2010 & 2013 & 2014 & 2015 & 2016 & 2017 & 2018 \\
\hline $\begin{array}{l}\text { 5. Видатки бюджету на охо- } \\
\text { рону навколишнього приро- } \\
\text { дного середовища, млн. грн. }\end{array}$ & 2872,4 & 5594,2 & 3481,7 & 5529,7 & 6255,4 & 7349,3 & 8242,1 & 286,94 \\
\hline Індекс, пункти & $X$ & 1,056 & 0,622 & 1,588 & 1,131 & 1,175 & 1,121 & $X$ \\
\hline $\begin{array}{l}\text { 6. Частка видатків бюджету } \\
\text { на охорону навколишнього } \\
\text { природного середовища у } \\
\text { загальному обсязі видатків } \\
\text { бюджету, \% }\end{array}$ & 0,8 & 1,1 & 0,7 & 0,8 & 0,7 & 0,7 & $\mathbf{0 , 7}$ & 87,50 \\
\hline $\begin{array}{l}\text { 7. Частка видатків бюджету } \\
\text { на охорону НПС у сукупних } \\
\text { витратах на НПС, \% }\end{array}$ & 21,88 & 27,45 & 15,88 & 22,49 & 19,25 & 23,34 & $\mathbf{2 3 , 9 6}$ & $\mathrm{X}$ \\
\hline
\end{tabular}

розраховано автором за даними Державної служби статистики України $[14,16]$.

За 2010-2018 рр. відбулися структурні зміни у складі сукупних витрат на охорону НПС: частка капітальних інвестицій зросла з $21 \%$ до 29,3\%, частка поточних витрат, навпаки, зменшилася з $79 \%$ до 70,7 \% відповідно. У 2018 р. вказана тенденція структурних змін посилилася (див. табл. 3).

У звітному році видатки бюджету на охорону НПС досягли 8,24 млрд. грн., збільшившись порівня- но з базовим періодом майже втричі, водночас їх частка у загальному обсязі бюджетних видатків зменшилася за 2010-2018 pp. $з$ 0,8 до 0,7 \% відповідно. Державний та місцевий бюджети є вагомим інвестором природоохоронних програм. У 2016 р. вони фінансували 6,0 \% сукупних витрат на охорону НПС, у 2017 p. $-8,2 \%$, у 2018 p. $-6,7 \%$ (рис. 2 ).

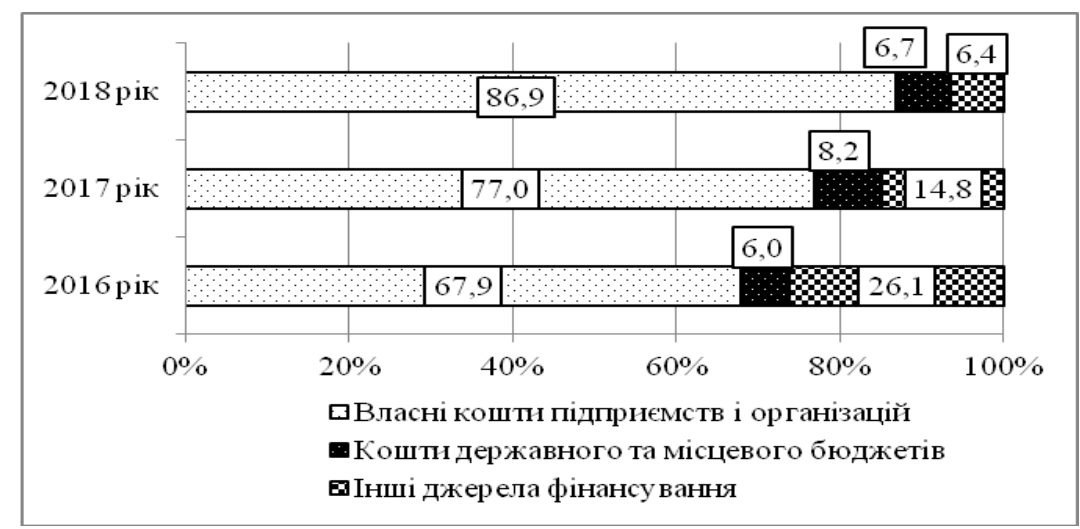

Рис. 2. Структура витрат на охорону НПС за джерелами фінансування, \%*

"розраховано автором за даними Державної служби статистики України $[14,16]$

За 2016-2018 рр. на фоні скорочення частки бюджетних коштів та інших джерел фінансування зросла питома вага власних коштів підприємств і організацій - 3 67,9 \% до 86,9 \% відповідно. Відтак, в Україні головними інвестором природоохоронних заходів є суб'єкти господарювання, які забезпечують $87 \%$ витрат на охорону НПС.

Структура капітальних інвестищій на охорону НПС в Україні за видами природоохоронних заходів (таблиця 4) є нестабільною, змінюється щороку, відображаючи певні домінанти ІІПП. Так, у 2010 р. найбільшу питому вагу у структурі екологічних капітальних інвестицій займали витрати на охорону атмосферного повітря (41,2\%), очищення зворотних вод $(26,6 \%)$ та поводження 3 відходами $(17,2 \%)$. У
2018 р. за структурою найбільша частка капітальних інвестицій була спрямована переважно на забезпечення радіаційної безпеки (20,2 \%), охорону атмосферного повітря $(34,8 \%)$, очищення зворотних вод (16,8 \%). За досліджуваний період динаміка структурних змін характеризувалася зменшенням питомої ваги практично всіх природоохоронних заходів на фоні зростання частки витрат на забезпечення радіаційної безпеки (на 20,1\%) та захист і реабілітацію грунту (на 2,8\%).

Вкрай негативною тенденцією є скорочення частки НДР природоохоронного спрямування з 0,3\% в 2010 р. до $0,1 \%$ в 2018 р., як інноваційної компоненти раціонального природокористування (див. табл. 4). 
Структура капітальних інвестицій на охорону НПС в Україні, \%*

\begin{tabular}{|c|c|c|c|c|c|c|}
\hline \multirow{2}{*}{ Природоохоронні заходи } & \multicolumn{5}{|c|}{ Роки } & \multirow{2}{*}{$\begin{array}{c}\text { Динаміка } \\
\text { 3мін (+,-) } \\
(5-1)\end{array}$} \\
\hline & 2010 & 2015 & 2016 & 2017 & 2018 & \\
\hline $\boldsymbol{A}$ & 1 & 2 & 3 & 4 & 5 & 6 \\
\hline $\begin{array}{l}\text { 1. Охорона атмосферного повітря і пробле- } \\
\text { ми зміни клімату }\end{array}$ & 41,2 & 18,5 & 18,6 & 23,7 & 34,8 & $-6,4$ \\
\hline 2. Очищення зворотних вод & 26,6 & 11,1 & 8,7 & 11,6 & 16,8 & $-9,8$ \\
\hline 3. Поводження з відходами & 17,2 & 9,6 & 16,5 & 22,4 & 11,7 & $-5,5$ \\
\hline $\begin{array}{l}\text { 4. Захист і реабілітація грунту, підземних і } \\
\text { поверхневих вод }\end{array}$ & 11,6 & 5,1 & 3,1 & 11,6 & 14,4 & $+2,8$ \\
\hline $\begin{array}{l}\text { 5. Зниження шумового і вібраційного } \\
\text { впливу }\end{array}$ & 0,4 & 0,5 & 0,7 & 1,5 & 0,6 & $+0,2$ \\
\hline $\begin{array}{l}\text { 6. Збереження біорізноманіття і середови- } \\
\text { ща існування }\end{array}$ & 0,7 & 0,3 & 0,4 & 1,6 & 0,7 & - \\
\hline 7. Радіаційна безпека & 0,1 & 54,8 & 51,9 & 27,3 & 20,2 & $+20,1$ \\
\hline 8. НДР природоохоронного спрямування & 0,3 & 0,03 & 0,02 & 0,03 & 0,1 & $-0,2$ \\
\hline 9.Інші види природоохоронної діяльності & 1,9 & 0,1 & 0,1 & 0,3 & 0,7 & $-1,2$ \\
\hline Усього: & 100 & 100 & 100 & 100 & 100 & - \\
\hline
\end{tabular}

" розраховано автором за даними Державної служби статистики України [16]

У звітному році обсяг капітальних інвестицій на фінансування науково-дослідних робіт склав 5,7 млн. грн., що на $25 \%$ менше рівня 2010 року; однак порівняно з 2015 р. він зріс у 2,7 рази. Водночас подвійне скорочення суми капітальних інвестицій на заходи поводження з відходами в звітному році порівняно $з$ попереднім обумовило зростання індикатора відходоємності ВВП в Україні.

Аналіз капітальних інвестицій за напрямами та видами природоохоронних заходів в Україні свідчить про те, що незважаючи на зростаючі обсяги, частка інвестицій в інтегровані технології за 20102018 рр зменшилася за більшістю природоохоронних заходів, водночас зросла питома вага такого напряму, як очищення. Так, у 2018 р. частка капітальних інвестицій в інтегровані технології за заходом охорона атмосферного повітря склала 14,7 \% (у 2013 р. $45,4 \%$ ), очищення зворотних вод - 18,2 \% (у 2012 р. $28,1 \%$ ), поводження з відходами - 3,8 \% (у 2012 р. $17,1 \%$ ). Виняток складають такі природоохоронні заходи, як захист і реабілітація грунту та радіаційна безпека, де впровадження інтегрованих технологій $є$ домінуючим напрямом капітального інвестування (85,2\% i 78,3\% у 2018 p.) [16].

Структура поточних інвестицій на охорону НПС в Україні за видами природоохоронних заходів наведена в таблиці 5. За досліджуваний період у структурі поточних екологічних інвестицій домінували заходи на очищення зворотних вод, поводження 3 відходами та охорону атмосферного повітря; у 2018 р. їх частки склали 39,6 \%, 36,3\% та 11,9\% відповідно.

Таблиця 5

Структура поточних інвестицій на охорону НПС в Україні, \%*

\begin{tabular}{|c|c|c|c|c|c|c|}
\hline \multirow{2}{*}{ Природоохоронні заходи } & \multicolumn{5}{|c|}{ Роки } & \multirow{2}{*}{$\begin{array}{c}\text { Динаміка } \\
\text { змін (+,-) } \\
(5-1)\end{array}$} \\
\hline & 2010 & 2015 & 2016 & 2017 & 2018 & \\
\hline $\boldsymbol{A}$ & 1 & 2 & 3 & 4 & 5 & 6 \\
\hline $\begin{array}{l}\text { 1. Охорона атмосферного повітря і проблеми } \\
\text { зміни клімату }\end{array}$ & 12,7 & 9,0 & 9,2 & 10,3 & 11,9 & $-0,8$ \\
\hline 2. Очищення зворотних вод & 48,6 & 39,3 & 40,8 & 39,4 & 39,6 & $-9,0$ \\
\hline 3. Поводження з відходами & 25,1 & 40,2 & 35,2 & 36,7 & 36,3 & $+11,2$ \\
\hline $\begin{array}{l}\text { 4. Захист і реабілітація грунту, підземних і } \\
\text { поверхневих вод }\end{array}$ & 4,6 & 6,8 & 6,3 & 4,8 & 5,3 & $+0,7$ \\
\hline 5. Зниження шумового і вібраційного впливу & 0 & 0,4 & 1,4 & 2,6 & 0,9 & $+0,9$ \\
\hline $\begin{array}{l}\text { 6. Збереження біорізноманіття і середовища } \\
\text { існування }\end{array}$ & 2,3 & 2,2 & 2,8 & 3,8 & 3,3 & $+1,0$ \\
\hline 7. Радіаційна безпека & 4,4 & 0,5 & 0,6 & 0,5 & 0,5 & $-3,9$ \\
\hline 8. НДР природоохоронного спрямування & 0,5 & 0,3 & 0,3 & 0,4 & 0,5 & - \\
\hline 9.Інші види природоохоронної діяльності & 1,8 & 1,3 & 3,4 & 1,5 & 1,7 & $-0,1$ \\
\hline Усього: & 100 & 100 & 100 & 100 & 100 & - \\
\hline
\end{tabular}

" розраховано автором за даними Державної служби статистики України [16] 
За 2010-2018 рр. динаміка структурних змін характеризувалася збільшенням питомої ваги заходів поводження 3 відходами (на 11,2\%) за рахунок скорочення частки поточного інвестування очищення зворотних вод (на 9\%) та радіаційної безпеки (на 3,9\%). У 2018 р. обсяг поточного фінансування НДР природоохоронного спрямування зріс порівняно 3 2010 р. вдвічі (з 57,6 до 118,5 млн. грн.), водночас їх частка залишилася незмінною на рівні 0,5\%. У звітному році порівняно 3 попереднім обсяг поточного інвестування заходів поводження 3 відходами збільшився на 17,6\%, порівняно з базовим 2010 р. - в 3,4 p. Аналізуючи структурні зміни екологічних інвестицій (див. табл. 4, 5), можна констатувати зміну пріоритетів інвестиційно-інноваційної політики держави у напрямі впровадження заходів поводження 3 відходами та забезпечення радіаційної безпеки, що, безумовно, вплинуло на індикатор продуктивності
ВВП за відходами.

В комплексному методичному забезпеченні аналітично значимою постає оцінка секторальної структури капітальних інвестицій та сукупних витрат на охорону НПС. Згідно проведених розрахунків, в Україні найбільша частка сукупних витрат на охорону НПС припадає на переробну промисловість - 30 \% в 2018 р. (з них 17,35 \% посідає металургійне виробництво), сектор водопостачання - 23,9\%, добувну промисловість і розроблення кар'єрів - 22,6 \% (3 них $21,1 \%$ припадає на добування металевих руд), сектор постачання електроенергії, газу, пари та кондиційованого повітря - 12,9\% (таблиця 6). Частки інших секторів національної економіки є незначними й досягають $1,22 \%$ для сільського господарства, 1,58 \% для харчової промисловості, 2,16 \% для транспорту, 2,89 \% для державного управління й оборони.

Секторальна структура сукупних витрат на охорону НПС в Україні, \%*

Таблиця 6

\begin{tabular}{|c|c|c|c|c|c|}
\hline \multirow{2}{*}{ Види економічної діяльності } & \multicolumn{4}{|c|}{ Роки } & \multirow{2}{*}{$\begin{array}{l}\text { Динаміка } \\
\text { змін }(+,-)\end{array}$} \\
\hline & 2015 & 2016 & 2017 & 2018 & \\
\hline 1. Сільське, лісове та рибне господарство & 1,42 & 1,13 & 1,36 & 1,22 & $-0,20$ \\
\hline 2. Добувна промисловість і розроблення кар'єрів & 21,24 & 15,98 & 18,95 & 22,62 & $+\mathbf{1 , 3 9}$ \\
\hline 2.1. у т.ч. добування металевих руд & 19,78 & 14,53 & 17,69 & 21,14 & $+1,36$ \\
\hline 3. Переробна промисловість, всього, у т.ч. & 25,03 & 23,84 & 25,42 & 30,02 & $+4,98$ \\
\hline 3.1. Виробництво харчових продуктів & 0,84 & 1,02 & 1,05 & 1,58 & $+0,74$ \\
\hline $\begin{array}{l}\text { 3.2. Виробництво коксу та продуктів нафтоперероб- } \\
\text { лення }\end{array}$ & 3,36 & 2,48 & 2,97 & 3,56 & $+0,20$ \\
\hline 3.3. Металургійне виробництво & 14,54 & 15,44 & 14,99 & 17,35 & $+2,81$ \\
\hline $\begin{array}{l}\text { 4. Постачання електроенергії, газу, пари та кондиційо- } \\
\text { ваного повітря }\end{array}$ & 22,05 & 29,56 & 19,52 & 12,86 & $-9,19$ \\
\hline $\begin{array}{l}\text { 5. Водопостачання; каналізація, поводження з відхода- } \\
\text { ми, всього, у т.ч. }\end{array}$ & 19,59 & 18,76 & 20,71 & $\mathbf{2 3 , 8 8}$ & $+4,29$ \\
\hline 5.1 Забір, очищення та постачання води & 12,94 & 12,97 & 12,60 & 13,14 & $+0,20$ \\
\hline 5.2. Каналізація, відведення й очищення стічних вод & 1,80 & 1,47 & 2,02 & 2,63 & $+0,83$ \\
\hline $\begin{array}{l}\text { 5.3. Збирання, оброблення й видалення відходів; відно- } \\
\text { влення матеріалів }\end{array}$ & 4,83 & 4,28 & 6,06 & 8,07 & $+3,24$ \\
\hline $\begin{array}{l}\text { 6. Оптова та роздрібна торгівля; ремонт автотранспортних } \\
\text { засобів і мотоциклів }\end{array}$ & 4,98 & 3,58 & 4,48 & 0,96 & $-4,02$ \\
\hline $\begin{array}{l}\text { 7.Транспорт, складське господарство, поштова та кур'єрська } \\
\text { діяльність }\end{array}$ & 1,26 & 2,52 & 1,83 & 2,16 & $+0,90$ \\
\hline 8. Професійна, наукова та технічна діяльність & 0,56 & 0,59 & 0,74 & 0,76 & $+0,20$ \\
\hline $\begin{array}{l}\text { 9. Діяльність у сфері адміністративного та допоміжного } \\
\text { обслуговування }\end{array}$ & 1,08 & 0,51 & 0,77 & 0,98 & $-0,11$ \\
\hline $\begin{array}{l}\text { 10. Державне управління й оборона; обов'язкове соціальне } \\
\text { страхування }\end{array}$ & 1,86 & 2,40 & 4,39 & 2,89 & $+1,03$ \\
\hline 11. Інші сектори економіки & 0,93 & 1,13 & 1,83 & 1,65 & $+0,72$ \\
\hline
\end{tabular}

розраховано автором за даними Державної служби статистики України $[14,15,16]$

За 2015-2018 рр. відбулися структурні зміни в секторальній структурі витрат на охорону НПС: частка енергосектору скоротилася на 9,19\%, натомість зросли частки переробної промисловості (на 4,98 \%), сектору водопостачання (на 4,29 \%) та добувної промисловості (на 1,39 \%) (див. табл. 6). У звітному році істотно зменшилася питома вага оптової та роздрібної торгівлі (на 4,02 \%); незначне скорочення було 
притаманне також сільському господарству (на 0,2 \%). Наочно структурні зміни сукупних витрат на охорону НПС у секторальному вимірі відображено на рис. 3.

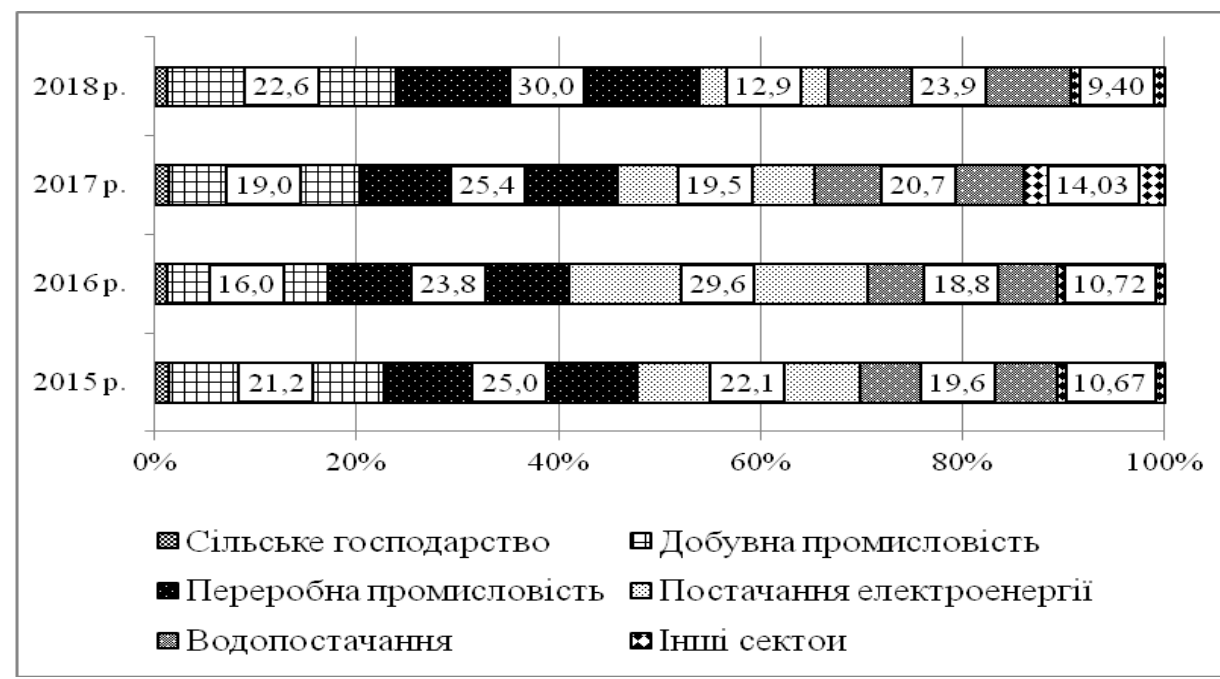

Рис. 3. Секторальна структура сукупних витрат на охорону НПС в Україні, \%* "побудовано автором за даними табл. 6.

У 2018 р. загальний обсяг екологічних інвестицій в національну економіку склав 34,4 млрд. грн., збільшившись порівняно з 2015 р. на 39,9 \%. Найбільший обсяг екоінвестицій здійснили підприємства переробної промисловості - 10,3 млрд. грн., що на 67,7\% більше рівня 2015 р. [16]. Друге і третє місце посіли сектор водопостачання (8,2 млрд. грн.) і добувна промисловість (7,8 млрд. грн.), наростивши обсяги інвестування раціонального природокористування на 70,5\% і 49 \% відповідно. Незважаючи на скорочення сукупних витрат на охорону НПС енергосектору на 18,4 \% в 2018 р. порівняно $з 2015$ р., він посів четверте місце у секторальній структурі екоінвестицій (див. рис. 2). За досліджуваний період обсяги екологічних інвестицій сільського господарства зросли на $20 \%$, що є позитивною тенденцією в сталому розвитку агросектору країни.

Проведений аналіз свідчить, що підприємства промислового сектору національної економіки здійс- нюють майже 90 \% капітальних і поточних витрат на охорону НПС. Відтак, головним суб'єктом інвестиційно-інноваційної політики раціонального природокористування в Україні є промислові підприємства. В Україні спостерігається позитивна тенденція зростання кількості впроваджених маловідходних та безвідходних технологій у промисловості (таблиця 7). У 2018 р. їх загальна кількість склала 926 од., збільшившись порівняно з 2010 р. на 93,3 \%. При цьому частка впроваджених ресурсозберігаючих технологій у загальному обсязі нових технологічних процесів зросла $323,45 \%$ в 2010 р. до 46,25 \% в 2018p., перевищивши навіть рівень 1995 р. У 2016 р. відбулося майже потрійне зростання кількості впроваджених інноваційних технологічних процесів у промисловості, у т.ч. кількість маловідходних ресурсозберігаючих i безвідходних технологій збільшилася на 63,3\%; у 2018 р. порівняно 3 2016р. приріст склав 23,4\%.

Таблиця 7

Кількість упроваджених нових технологічних процесів у промисловості України, одиниць

\begin{tabular}{|c|c|c|c|c|c|c|c|c|c|}
\hline \multirow{2}{*}{ Показники } & \multicolumn{8}{|c|}{ Роки } & \multirow{2}{*}{$\begin{array}{l}2018 \text { p. y } \\
\% \text { до } 2010\end{array}$} \\
\hline & 1995 & 2000 & 2005 & 2010 & 2015 & 2016 & 2017 & 2018 & \\
\hline $\begin{array}{l}\text { 1. Впроваджено нових тех- } \\
\text { нологічних процесів }\end{array}$ & 2936 & 1403 & 1808 & 2043 & 1217 & 3489 & 1831 & 2002 & 98,0 \\
\hline $\begin{array}{l}\text { 2. У т.ч. маловідходних } \\
\text { ресурсозберігаючих і без- } \\
\text { відходних технологій }\end{array}$ & 1044 & 430 & 690 & 479 & 458 & 748 & 611 & 926 & 193,3 \\
\hline $\begin{array}{l}2.1 . У \text { \% до нових технологі- } \\
\text { чних процесів }\end{array}$ & 35,56 & 30,65 & 38,16 & 23,45 & 37,63 & 21,44 & 33,37 & 46,25 & X \\
\hline
\end{tabular}

"розраховано автором за даними Державної служби статистики України [14].

У 2018 р. обсяг реалізованої інноваційної продукції в промисловості України склав 24,86 млрд. грн., збільшившись порівняно з 2015 р. на 7,9 \% (таб- лиця 8). Частка переробної промисловості в обсязі реалізованої інноваційної продукції промислового сектору досягла 98,26 \%, у т.ч. 25,31 \% припадало на 
харчову промисловість, 15,07 \% - виробництво автотранспортних засобів, 14,96 \% - металургійне виробництво. Частка добувної промисловості у сектораль- ній структурі інноваційної продукції $є$ незначною і складає $1,23 \%$, секторів постачання електроенергії та води - 0,46 \% і 0,04 \% відповідно.

Таблиця 8

Обсяг та структура реалізованої інноваційної продукції (товарів, послуг) за видами економічної діяльності промисловості України"

\begin{tabular}{|c|c|c|c|c|c|c|}
\hline \multirow[b]{2}{*}{ Сектори промислової діяльності } & \multicolumn{2}{|c|}{2015 рік } & \multicolumn{2}{|c|}{2018 рік } & \multicolumn{2}{|c|}{ Динаміка змін } \\
\hline & $\begin{array}{l}\text { Млн. } \\
\text { грн. }\end{array}$ & $\%$ & $\begin{array}{l}\text { Млн. } \\
\text { грн. }\end{array}$ & $\%$ & $\begin{array}{c}\text { Темп } \\
\text { росту, \% } \\
(3 / 1) \\
\end{array}$ & $\begin{array}{l}\text { Зміни струк- } \\
\text { тури, \% (4-2) }\end{array}$ \\
\hline$A$ & 1 & 2 & 3 & 4 & 5 & 6 \\
\hline $\begin{array}{l}\text { Усього промисловість, } \\
\text { в тому числі: }\end{array}$ & 23050,1 & 100 & 24861,1 & 100,00 & 107,9 & $\mathbf{X}$ \\
\hline $\begin{array}{l}\text { 1. Добувна промисловість і розроблення } \\
\text { кар'єрів }\end{array}$ & 53,7 & 0,23 & 306,7 & 1,23 & 571,1 & $+1,00$ \\
\hline 2. Переробна промисловість & 22897,9 & 99,34 & 24429,1 & 98,26 & 106,7 & $-1,08$ \\
\hline 2.1. Виробництво харчових продуктів & 4874,5 & 21,15 & 6292,4 & 25,31 & 129,1 & $+4,16$ \\
\hline $\begin{array}{l}\text { 2.2. Виробництво неметалевої мінера- } \\
\text { льної продукції }\end{array}$ & 565,5 & 2,45 & 2092,2 & 8,42 & 370,0 & $+5,96$ \\
\hline 2.3. Металургійне виробництво & 6174,6 & 26,79 & 3718,7 & 14,96 & 60,2 & $-11,83$ \\
\hline $\begin{array}{l}\text { 2.4. Виробництво комп’ютерів, елект- } \\
\text { ронної та оптичної продукції }\end{array}$ & 466,1 & 2,02 & 1044,9 & 4,20 & 224,2 & $+2,18$ \\
\hline $\begin{array}{l}\text { 2.5. Виробництво електричного устат- } \\
\text { кування }\end{array}$ & 1389 & 6,03 & 1382,7 & 5,56 & 99,5 & $-0,46$ \\
\hline $\begin{array}{l}\text { 2.6. Виробництво інших машин і устат- } \\
\text { кування }\end{array}$ & 3276,9 & 14,22 & 1854,8 & 7,46 & 56,6 & $-6,76$ \\
\hline $\begin{array}{l}\text { 2.7. Виробництво автотранспортних за- } \\
\text { собів }\end{array}$ & 2187,2 & 9,49 & 3746,7 & 15,07 & 171,3 & $+5,58$ \\
\hline $\begin{array}{l}\text { 3. Постачання електроенергіï, газу, пари } \\
\text { та кондиційованого повітря }\end{array}$ & 95,8 & 0,42 & 114,7 & 0,46 & 119,7 & $+0,05$ \\
\hline $\begin{array}{l}\text { 4. Водопостачання; } \\
\text { дження з відходамізація, }\end{array}$ & 2,79 & 0,01 & 10,6 & 0,04 & 379,9 & $+0,03$ \\
\hline
\end{tabular}

"розраховано автором за даними Державної служби статистики України $[14,15]$.

У звітному році найбільший приріст обсягів реалізованої інноваційної продукції був характерний для добувної промисловості (в 5,7 рази), виробництва неметалевої мінеральної продукції (в 3,7 рази), виробництва комп'ютерів та автотранспортних засобів (в 2,2 і 1,7 рази відповідно). За 2015-2018 рр. секторальна структура реалізованої інноваційної продукції змінилася в бік скорочення частки металургійного виробництва (на 11,83 \%) і зростання питомої ваги виробництва автотранспортних засобів (на 5,58 \%) та неметалевої мінеральної продукції (на 5,96 \%) (див. табл. 8).

Стратегією сталого розвитку України передбачено цільове значення індикатора частки реалізованої інноваційної продукції в обсязі промислової на рівні $5 \%$ в 2020 р. і $10 \%$ в 2025 р. [5, с.71]. За даними Держстату, у 2018 р. рівень даного індикатора для економіки в цілому склав лише $0,8 \%$, у т.ч. добувна промисловість - 0,1\%, переробна - 1,3\%. Всього три сектори економіки в 2018 р. досягли цільового значення індикатора: виробництво автотранспортних засобів (5\%), комп'ютерів, електронної та оптичної продукції (5,8 \%), поліграфічна діяльність (7,7 \%) [14].

Якісна оцінка динаміки змін індикаторів інвестиційно-інноваційного забезпечення раціонального природокористування України представлена в таблиці 9. Незважаючи на зростання частки капітальних інвестицій на охорону НПС в загальних інвестиціях, питома вага і капітальних, і сукупних екологічних інвестицій у ВВП скорочується та $є$ нижчою рівня європейських держав. Частка видатків бюджету на охорону НПС у загальному їх обсязі зменшується, питома вага коштів державного й місцевого бюджетів у фінансуванні витрат на охорону НПС теж скорочується. Означені тенденції є негативними, сигналізуючи, $з$ одного боку, про недостатність інвестицій для екологобезпечного функціонування національної економіки, з іншого, про зміну пріоритетів державної політики, послаблення ступені участі держави в процесах раціонального природокористування як інвестора і як регулятора, що є наслідком зміни моделі змішаного регулювання на ринкове саморегулювання економіки. 
Якісна оцінка динаміки змін індикаторів інвестиційно-інноваційного забезпечення раціонального природокористування України"

\begin{tabular}{|c|c|c|}
\hline Показники & $\begin{array}{c}\text { Динаміка змін: } \\
\text { зростання } \uparrow \\
\text { зменшення } \downarrow\end{array}$ & $\begin{array}{c}\text { Оцінка } \\
\text { динаміки: } \\
\text { П; Н; Б3; } \\
\text { ЦНД; ЦД, ДД }\end{array}$ \\
\hline 1 & 2 & 3 \\
\hline
\end{tabular}

1. Частка екологічних інвестицій у ВВП та видатки бюджету на охорону НПС

1.1. Частка капітальних інвестицій на охорону НПС до загальних капітальних інвестицій в економіці, \%

1.2. Частка капітальних інвестицій на охорону НПС у ВВП, \%

1.3. Частка сукупних витрат на охорону НПС у ВВП, \%

1.4. Частка видатків бюджету на охорону навколишнього природного середовища у загальному обсязі видатків бюджету, \%

1.5. Частка коштів державного й місцевого бюджетів у фінансуванні витрат на охорону НПС, \%

\begin{tabular}{|c|c|c|}
\hline$\uparrow$ & $\Pi$ \\
\hline & $\downarrow$ & Н \\
\hline & $\downarrow$ & Н, ЦНД \\
\hline & $\downarrow$ & $\mathrm{H}$ \\
\hline
\end{tabular}

\section{2. Оцінка динамічних та структурних змін капітальних інвестицій на охорону НПС}

2.1. Індекс капітальних інвестицій на охорону НПС, \% до 2010 р.

2.2. Індекс капітальних інвестицій на охорону НПС в науководослідні роботи природоохоронного спрямування, \% до 2010 р.

2.3. Питома вага капітальних інвестицій у структурі сукупних витрат на охорону НПС, \%

2.4. Питома вага інвестицій в інтегровані технологї̈ в капітальних інвестиціях на охорону НПС за видами природоохоронних заходів (порівняно з 2010 р.), \%:

\begin{tabular}{|c|c|c|}
\hline 2.4.1. Охорона атмосферного повітря і проблеми зміни клімату & $\downarrow$ & $\mathbf{H}$ \\
\hline 2.4.2. Очищення зворотних вод & $\downarrow$ & $\mathbf{H}$ \\
\hline 2.4.3. Поводження з відходами & $\downarrow$ & $\mathrm{H}$ \\
\hline 2.4.4. Захист і реабілітація грунту, підземних і поверхневих вод & $\downarrow$ & $\mathrm{H}$ \\
\hline 2.4.5. Радіаційна безпека & $\uparrow$ & $\Pi$ \\
\hline \multicolumn{3}{|l|}{$\begin{array}{l}\text { 2.5. Структурні зміни капітальних інвестицій на охорону НПС за } \\
\text { видами природоохоронних заходів (порівняно з } 2010 \text { р.), \%: }\end{array}$} \\
\hline 2.5.1. Охорона атмосферного повітря і проблеми зміни клімату & $\downarrow$ & ДД \\
\hline 2.5.2. Очищення зворотних вод & $\downarrow$ & ДД \\
\hline 2.5.3. Поводження з відходами & $\downarrow$ & $\mathbf{H}$, ДД \\
\hline 2.5.4. Захист і реабілітація грунту, підземних і поверхневих вод & $\downarrow$ & ДД \\
\hline 2.5.5. Радіаційна безпека & $\uparrow$ & ДД \\
\hline 2.5.6. НДР природоохоронного спрямування & $\downarrow$ & $\mathbf{H}$, ДД \\
\hline \multicolumn{3}{|l|}{$\begin{array}{l}\text { 2.6. Структурні зміни капітальних інвестицій на охорону НПС за } \\
\text { секторами національної економіки (порівняно з } 2015 \text { р.), \%: }\end{array}$} \\
\hline 2.6.1. Сільське, лісове та рибне господарство & $\downarrow$ & ДД \\
\hline 2.6.2. Добувна промисловість і розроблення кар'єрів & $\uparrow$ & ДД \\
\hline 2.6.3. Переробна промисловість & $\uparrow$ & ДД \\
\hline $\begin{array}{l}\text { 2.6.4. Постачання електроенергії, газу, пари та кондиційованого } \\
\text { повітря }\end{array}$ & $\downarrow$ & ДД \\
\hline 2.6.5. Водопостачання; каналізація, поводження з відходами & $\uparrow$ & ДД \\
\hline 2.6.6. Інші сектори економіки & $\uparrow$ & ДД \\
\hline $\begin{array}{l}\text { 2.7. Питома вага капітальних інвестицій на охорону НПС в загальних } \\
\text { капітальних інвестиціях секторів національної економіки }\end{array}$ & $\downarrow$ & $\mathbf{H}$ \\
\hline \multicolumn{3}{|c|}{ 3. Оцінка динамічних та структурних змін поточних інвестицій на охорону НПС } \\
\hline 3.1. Індекс поточних інвестицій на охорону НПС, \% до 2010 р. & $\uparrow$ & $\Pi$ \\
\hline $\begin{array}{l}\text { 3.2. Питома вага поточних інвестицій у структурі сукупних витрат на } \\
\text { охорону НПС, \% }\end{array}$ & $\downarrow$ & $\Pi$ \\
\hline
\end{tabular}


Продовження табл. 9

\begin{tabular}{|c|c|c|}
\hline Показники & $\begin{array}{c}\text { Динаміка змін: } \\
\text { зростання } \uparrow \\
\text { зменшення } \downarrow\end{array}$ & $\begin{array}{c}\text { Оцінка } \\
\text { динаміки: } \\
\text { П; Н; БЗ; } \\
\text { ЦНД; ЦД, ДД** }\end{array}$ \\
\hline 1 & 2 & 3 \\
\hline \multicolumn{3}{|l|}{$\begin{array}{l}\text { 3.3. Структурні зміни поточних інвестицій на охорону НПС за } \\
\text { видами природоохоронних заходів (порівняно з } 2010 \text { р.), \%: }\end{array}$} \\
\hline 3.3.1. Охорона атмосферного повітря і проблеми зміни клімату & $\downarrow$ & ДД \\
\hline 3.3.2. Очищення зворотних вод & $\downarrow$ & ДД \\
\hline 3.3.3. Поводження з відходами & $\uparrow$ & ДД \\
\hline 3.3.4. Захист і реабілітація грунту, підземних і поверхневих вод & $\uparrow$ & ДД \\
\hline 3.3.5. Радіаційна безпека & $\downarrow$ & ДД \\
\hline 3.3.6. НДР природоохоронного спрямування & - & Б3 \\
\hline \multicolumn{3}{|l|}{$\begin{array}{l}\text { 3.4. Структурні зміни поточних інвестицій на охорону НПС за } \\
\text { секторами національної економіки (порівняно з } 2015 \text { р.), \%: }\end{array}$} \\
\hline 3.4.1. Сільське, лісове та рибне господарство & $\downarrow$ & ДД \\
\hline 3.4.2. Добувна промисловість і розроблення кар'єрів & $\downarrow$ & ДД \\
\hline 3.4.3. Переробна промисловість & $\uparrow$ & ДД \\
\hline $\begin{array}{l}\text { 3.4.4. Постачання електроенергї, газу, пари та кондиційованого } \\
\text { повітря }\end{array}$ & $\downarrow$ & ДД \\
\hline 3.4.5. Водопостачання; каналізація, поводження з відходами & $\uparrow$ & ДД \\
\hline 3.4.6. Інші сектори економіки & $\uparrow$ & ДД \\
\hline \multicolumn{3}{|c|}{ 4. Оцінка динамічних змін сукупних витрат на охорону НПС } \\
\hline 4.1. Індекс сукупних витрат на охорону НПС, \% до 2010 р. & $\uparrow$ & П \\
\hline \multicolumn{3}{|l|}{$\begin{array}{l}\text { 4.2. Індекс сукупних витрат на охорону НПС за секторами націо- } \\
\text { нальної економіки (порівняно } 32015 \text { р.), \%: }\end{array}$} \\
\hline 4.2.1. Сільське, лісове та рибне господарство & $\uparrow$ & $\Pi$ \\
\hline 4.2.2. Добувна промисловість і розроблення кар'єрів & $\uparrow$ & $\Pi$ \\
\hline 4.2.3. Переробна промисловість & $\uparrow$ & $\Pi$ \\
\hline $\begin{array}{l}\text { 4.2.4. Постачання електроенергії, газу, пари та кондиційованого } \\
\text { повітря }\end{array}$ & $\downarrow$ & $\mathrm{H}$ \\
\hline 4.2.5. Водопостачання; каналізація, поводження з відходами & $\uparrow$ & $\Pi$ \\
\hline 4.2.6. Інші сектори економіки & $\uparrow$ & $\Pi$ \\
\hline \multicolumn{3}{|c|}{ 5. Інноваційна діяльність промислового сектору економіки } \\
\hline $\begin{array}{l}\text { 5.1. Індекс впроваджених маловідходних ресурсозберігаючих і безві- } \\
\text { дходних технологій, \% до } 2010 \text { р. }\end{array}$ & $\uparrow$ & $\Pi$ \\
\hline $\begin{array}{l}\text { 5.2.Частка впроваджених маловідходних ресурсозберігаючих і безві- } \\
\text { дходних технологій у нових технологічних процесах, \% }\end{array}$ & $\uparrow$ & $\Pi$ \\
\hline $\begin{array}{l}\text { 5.3. Індекс реалізованої інноваційної продукції в промисловості, \% до } \\
2015 \text { р. }\end{array}$ & $\uparrow$ & П; ЦНД \\
\hline
\end{tabular}

"складено автором на підставі даних таблиць 2-8;

** умовні позначення: П - позитивна динаміка; Н - негативна; Б3 - без значних змін; ЦНД - цільове значення показника не досягнуто; ЦД - цільове значення показника досягнуто; ДД - оцінка потребує додаткових досліджень.

За досліджуваний період загальний індекс капітальних інвестицій на охорону НПС і часткові індекси за видами природоохоронної діяльності зросли, за винятком інвестицій в НДР природоохоронного спрямування. Це є свідченням інвестиційного незабезпечення розвитку інноваційної компоненти раціонального природокористування, другорядності питань наукових досліджень. Незважаючи на позитивну тенденцію зростання питомої ваги капітальних інвестицій у структурі сукупних витрат на охорону НПС, частка вкладень у інтегровані технології в структурі капінвестицій зменшилася в 2018p. порівняно 3 2010 р. практично за всіма видами природоохоронної діяльності, окрім радіаційної безпеки. Така тенденція $\epsilon$ свідченням скорочення інвестування інноваційних технологій у сфері природокористування.

Напрям структурних змін поточних і капітальних витрат на охорону НПС обумовлений, зокрема, пріоритетами інвестиційної політики, які щороку змінюються під впливом дії множини внутрішніх і зовнішніх чинників. На наш погляд, до негативних змін доцільно віднести скорочення часток заходів пово- 
дження 3 відходами та НДР природоохоронного спрямування в структурі екологічних капітальних інвестицій. Загалом розширена інтерпретація структурних змін екоінвестицій потребує додаткових досліджень із врахуванням впливу сукупності чинників.

У секторальній структурі капітальних інвестицій за період 2010-2018pр. скоротилася частки аграрного та енергетичного секторів на фоні зростання питомої ваги інших секторів; у структурі поточних інвестицій знижувальний тренд мала, окрім вказаних двох секторів, і добувна промисловість (див. табл. 9). Розширена інтерпретація змін секторальної структури екоінвестицій вимагає додаткових досліджень 3 урахуванням особливостей інвестиційного й відтворювального розвитку різних секторів. Водночас існуюча тенденція до зниження питомої ваги капінвестицій на охорону НПС в загальних капітальних інвестиціях секторів національної економіки є однозначно негативною.

За 2015-2018 pр. загальний індекс сукупних витрат на охорону НПС і часткові індекси за секторами національної економіки зросли, за винятком екоінвестицій сектору постачання електроенергії, газу, пари та кондиційованого повітря, що обумовлено, передусім, скороченням обсягів виробництва. Динаміка індикаторів, що характеризують інноваційну діяльність промислового сектору національної економіки (див. табл. 9), є позитивною, сигналізуючи про зростання кількості впроваджених маловідходних та безвідходних технологій у промисловості. Порівняно з базовим 2015 р. обсяги реалізованої інноваційної продукції суб'єктами промислового сектору теж зросли, однак за індикатором ії частки в обсязі промислової продукції цільового значення 2020 р. досягнуто не було.

Висновки та перспективи подальших досліджень. У ході дослідження обгрунтовано теоретико - методичний базис комплексної оцінки домінант ІІПП на засадах концепцій сталого розвитку та інноваційної «квадро-спіралі», запропоновано авторське визначення категорій «домінанта» та «інвестиційноінноваційна політика природокористування». Визначено домінанти (стратегічні пріоритети) ІІПП національної економіки та відповідні їм групи оціночних індикаторів, обгрунтовано методологічний підхід до комплексної оцінки домінант ІІПП у двоєдності концептуального та методичного базисів, принципи та методичні положення такої оцінки. На основі розробленого методичного забезпечення здійснено діагностику трьох домінант ІІПП, пов'язаних з використанням інвестиційно-інноваційного потенціалу України, 3 акцентом на секторальний вимір, структурні співвідношення та сталий розвиток економіки.

На підставі проведеної оцінки встановлено негативні тенденції до скорочення частки екологічних інвестицій у ВВП, частки видатків бюджету на охорону НПС, обсягів інвестицій в НДР природоохоронного спрямування, капітальних інвестицій на заходи поводження з відходами, що є свідченням недо- статності інвестицій для еколобезпечного функціонування економіки та наявності структурних дисбалансів у їх перерозподілі. Головним суб'єктом ІІПП в Україні є промислові підприємства, які фінансують майже $90 \%$ сукупних витрат на охорону НПС та впровадження більшості екологічних інновацій у господарську практику.

Роль держави, як регулятора процесів природокористування та охорони довкілля в Україні, є незначною і забезпечується домінуванням примусовообмежувальних методів. Однак інвестиційноінноваційна політика на основі переважання примусово-обмежувальних регуляторів у кризових соціально-економічних умовах недостатньо стимулює зменшення техногенних навантажень на природу та дотримання усіма суб'єктами екологічних нормативів. Головною причиною цього $є$ невисокий розмір платежів за довкілля, низькі суми штрафів за природоохоронні порушення порівняно 3 вартістю діяльності щодо ліквідації цих порушень [17]. Відтак, виникає необхідність у збалансуванні примусовообмежувальних та стимулюючо-компенсаційних методів регулювання в ході вдосконалення інвестиційно-інноваційної політики природокористування в Україні.

Таким чином, проведена багатокомпонентна оцінка трьох домінант ІІПП національної економіки за допомогою системи індикаторів (див. рис. 1) свідчить про їх відносно низький ступінь впровадження, тобто про недостатнє інвестиційне забезпечення раціонального природокористування України на інноваційній основі та структурні дисбаланси у перерозподілі коштів між видами природоохоронних заходів та секторами національної економіки. Їх подолання обумовлює необхідність вдосконалення діючих методів і форм регулювання процесів природокористування, впровадження адаптивних стимулюючих механізмів із використанням європейських практик.

Наукова новизна проведеного дослідження полягає в розвитку теоретико-методологічного забезпечення раціонального природокористування шляхом удосконалення понятійно-категоріального апарату ІІПП, розробки методичного забезпечення щодо комплексної оцінки домінант ІІПП на засадах концепцій сталого розвитку та інноваційної «квадро-спіралі» 3 акцентом на секторально-структурний вимір. Прикладне значення отриманих результатів визначається можливістю їх використання різними стейкхолдерами в ході комплексної оцінки ІІПП, визначення іï ефективності та сучасних трендів, вдосконалення механізмів стимулювання та інституційного середовища раціонального природокористування в Україні. Перспективи подальших досліджень полягають у проведенні комплексної оцінки останніх трьох домінант ІІПП (див. рис. 1), визначення тенденцій сталого використання природно-ресурсного потенціалу, екоємності ВВП та екологічних аспектів якості життя населення. 


\section{Література}

1. Цілі Сталого розвитку 2016-2030. URL: http://www.un.org.ua/ua/tsili-rozvytku-tysiacholittia/tsilistaloho-rozvytku (дата звернення 06.08.2020).

2. Стратегія сталого розвитку України до 2030 року (проект). URL: https://www.undp.org/content/dam/ukraine/docs/SDGreports/UNDP_Strategy_v06-optimized.pdf (дата звернення 06.08.2020).

3. Про Цілі сталого розвитку України на період до 2030 року: Указ Президента України від 30 вересня 2019 р. № 722/2019. URL: https://zakon.rada.gov.ua/laws/show/722/2019 (дата звернення 06.08.2020).

4. Доповідь про зелену трансформацію в Україні на основі показників зеленого зростання ОЕСР. Київ: Міністерство економічного розвитку і торгівлі України, 2016. 60 с.

5. Цілі Сталого Розвитку: Україна: Національна доповідь 2017. Київ: Міністерство економічного розвитку і торгівлі України, 2017. 176 с.

6. Андрєєва Н.М., Тютюнник Г.О. Методичні підходи щодо визначення домінант регіональної інвестиційно-інноваційної політики природокористування: наукова доповідь. Одеса: ІПРЕЕД НАН України, 2020. $101 \mathrm{c}$.

7. Методичні рекомендації до оцінки впливу економічних показників на головні індикатори «зеленого» зростання / Буркинський Б.В., Нікішина О.В., Андрєєва Н.М. та ін. Одеса: ІПРЕЕД НАН України, 2019. 45 c.

8. Carayannis, E. G. Bart, T.D., \& Campbell D.F.J. (2012). The quintuple helix innovation model: global warning as a challenge and driver for innovation. Journal of Innovation and Entrepreneurship. № 1(1). Pp. 1-12. doi: $10.1186 / 2192-5372-1-2$

9. Румянцева Е. Е. Новая экономическая энциклопедия. Москва: ИНФРА-М, 2005. 724 с. 2002. $952 \mathrm{c}$.

10. Економічна енциклопедія / Відп. ред. С.В. Мочерний. Т.ІІІ. Київ: Видавничий центр «Академія», 2000. $848 \mathrm{c}$.

11. Економічна енциклопедія / Відп. ред. С.В. Мочерний. Т.ІІ. Київ: Видавничий центр «Академія»,

12. Економічна енциклопедія / Відп. ред. С.В. Мочерний. Т.І. Київ: Видавничий центр «Академія», 2000. $863 \mathrm{c}$.

13. Політологія. Зміст категорії URL: https://pidru4niki.com/1056112736310/politologiya/scho_take_politika (дата звернення 07.08.2020).

14. Офіційний сайт Державної служби статистики України. URL: http://www.ukrstat.gov.ua/ (дата звернення 07.08.2020).

15. Статистичний щорічник України за 2018 рік / за ред. І.С.Вернера. Київ: Державна служба статистики України, 2019.482 с.

16. Довкілля України за 2018 рік: статистичний збірник / за ред. О. М. Прокопенко. Київ: Державна служба статистики України, 2019. 214 с.

17. Костюк У.З. Фінансування природоохоронної діяльності в Україні: сучасний стан та шляхи покращення. Інноваційна економіка. 2015. № 1. С. 181-186.

Стаття надійшла 11.08.2020

Стаття прийнята до друку 25.08.2020

Доступно в мережі Internet 15.10.2020

Никишина О.В.

доктор экономических наук, старший научный сотрудник, заведующий отделом рыночных механизмов и структур

Институт проблем рынка и экономико-

экологических исследований НАН Украины

Французский бульвар, 29, г. Одесса, Украина, 65044

E-mail: ksenkych@gmail.com.

ORCID ID: 0000-0002-7172-3551

\section{ТЕОРЕТИКО-МЕТОДИЧЕСКИЕ ПОЛОЖЕНИЯ ПО КОМПЛЕКСНОЙ ОЦЕНКЕ ДОМИНАНТ ИНВЕСТИЦИОННО-ИННОВАЦИОННОЙ ПОЛИТИКИ ПРИРОДОПОЛЬЗОВАНИЯ УКРАИНЫ}

Статья посвящена обоснованию теоретико-методического обеспечения по комплексной оценки доминант инвестиционно-инновационной политики природопользования национальной экономики на основе концепций устойчивого развития и инновационной «квадро-спирали». Усовершенствован поня- 
тийно-категориальный аппарат исследования, разработан методологический подход к комплексной оценке доминант политики, объединивший концептуальный и методический базисы. Обоснованы цель, принципы и методические положения по комплексной оценки доминант политики с акцентом на секторально-структурное измерение.

Определены шесть доминант (стратегических приоритетов) инвестиционно-инновационной политики природопользования: (1) достаточное инвестиционное обеспечение рационального природопользования; (2) оптимальное перераспределение инвестиций между видами природоохранных мероприятий и секторами экономики; (3) стимулирование инвестиционного обеспечения инновационной деятельности в природопользовании; (4) восстановление, устойчивое использование и охрана составляющих природно-ресурсного потенциала национальной экономики; (5) снижение экодеструктивного влияния социально-экономической системы на состояние природной среды; (6) повышение экологических аспектов качества жизни населения. Для каждой доминанты предложены соответствующие ей группы оценочных индикаторов.

На основе разработанного методического обеспечения проведена диагностика трех доминант политики природопользования, связанных с использованием инвестиционно-инновационного потенциала Украины, определены современные тренды и проблемы его использования. В частности, установлено негативные тенденции к сокращению доли экологических инвестиций в ВВП, доли расходов бюджета на охрану природной среды, объемов инвестиций в научно-исследовательские разработки природоохранного направления, капитальных инвестиций на мероприятия по обращению с отходами. Главным субъектом инвестиционно-инновационной политики природопользования в Украине являются промышленные предприятия, которые финансируют почти 90\% совокупных расходов на охрану природной среды и внедрение большинства экологических инноваций в хозяйственную практику.

Результаты комплексной оценки показали низкую степень внедрения доминант политики. Обоснована целесообразность сбалансирования принудительно-ограничительных и стимулирующекомпенсационных методов регулирования в ходе совершенствования инвестиционно-инновационной политики природопользования в Украине.

Ключевые слова: природопользование, оценка, индикаторы, устойчивое развитие, инвестиционно-инновационная политика, инвестиции, сектора экономики.

Nikishyna 0.

Doctor of Economics, Senior Researcher

Head of Department of Market Mechanisms and Structures

Institute of Market Problems and Economic \& Ecological Research

of National Academy of Sciences of Ukraine

Frantsuzskiy boulevard, 29, Odesa, Ukraine, 65044

E-mail: ksenkych@gmail.com

ORCID ID: 0000-0002-7172-3551

\section{THEORETICAL AND METHODOLOGICAL PROVISIONS FOR A COMPREHENSIVE ASSESSMENT OF DOMINANTS OF INVESTMENT AND INNOVATIVE POLICY OF NATURE MANAGEMENT OF UKRAINE}

The article is devoted to the substantiation of theoretical and methodological support for a comprehensive assessment of the dominants of investment and innovation policy of nature management of the national economy on the basis of the concepts of sustainable development and innovative "quadro-spiral». The conceptual and categorical apparatus of the research has been improved, a methodological approach to a comprehensive assessment of policy dominants has been developed, combining conceptual and methodological bases. The purpose, principles and methodological provisions for a comprehensive assessment of dominants of policy with an emphasis on the sectoral-structural dimension have been substantiated.

Six dominants (strategic priorities) of investment and innovative policy of nature management have been defined: (1) sufficient investment provision of rational nature use; (2) optimal redistribution of investments between types of environmental measures and sectors of the economy; (3) stimulating of investment support for innovative activities in nature management; (4) restoration, sustainable use and protection of components of the natural resource potential of the national economy; (5) reducing of the eco-destructive impact of the socioeconomic system on the environment; (6) improving the environmental aspects of the quality of life of the population. For each dominant, the corresponding groups of evaluation indicators have been proposed.

On the basis of the developed methodological support the diagnostics of three dominants of nature management policy connected with the use of investment and innovative potential of Ukraine has been carried out, modern trends and problems of its use have been determined. In particular, there are negative trends to 
reduce the share of environmental investment in GDP, the share of budget expenditures on environmental protection, the volume of investment in research and development of environmental protection, capital investment in waste management measures. The main subject of investment and innovative policy of nature management in Ukraine are industrial enterprises, which finance almost $90 \%$ of the total costs of environmental protection and the introduction of most environmental innovations in economic practice.

The results of the comprehensive assessment showed a low degree of implementation of dominants of policy. The expediency of balancing coercive-restrictive and stimulating-compensatory methods of regulation in the course of improvement of investment-innovative policy of nature management in Ukraine has been substantiated.

Key words: nature management, assessment, indicators, sustainable development, investment and innovative policy, investments, sectors of the economy.

\section{References}

1. Tsili Staloho rozvytku 2016-2030. Retrieved August 6, 2020, from http://www.un.org.ua/ua/tsili-rozvytkutysiacholittia/tsili-staloho-rozvytku

2. Stratehiia staloho rozvytku Ukrainy do 2030 roku (proekt). Retrieved August 6, 2020, from https://www.undp.org/content/dam/ukraine/docs/SDGreports/UNDP_Strategy_v06-optimized.pdf

3. Pro Tsili staloho rozvytku Ukrainy na period do 2030 roku: Ukaz Prezydenta Ukrainy vid 30 veresnia 2019 r. № 722/2019. (2019). Retrieved August 6, 2020, from https://zakon.rada.gov.ua/laws/show/722/2019

4. Dopovid pro zelenu transformatsiiu v Ukraini na osnovi pokaznykiv zelenoho zrostannia OESR. (rep.). (2016). Kyiv: Ministerstvo ekonomichnoho rozvytku i torhivli Ukrainy.

5. Tsili Staloho Rozvytku: Ukraina (rep.). (2017). Kyiv: Ministerstvo ekonomichnoho rozvytku i torhivli Ukrainy.

6. Andrieieva, N. M., \& Tiutiunnyk, H. O. (2020). Metodychni pidkhody shchodo vyznachennia dominant rehionalnoi investytsiino-innovatsiinoi polityky pryrodokorystuvannia (rep.).Odesa: IPREED NAN Ukrainy.

7. Burkynskyi, B. V., Nikishyna, O. V., \& Andrieieva N. M. (2019). Metodychni rekomendatsii do otsinky vplyvu ekonomichnykh pokaznykiv na holovni indykatory «zelenoho» zrostannia. Odesa: IPREED NAN Ukrainy.

8. Carayannis, E. G., Bart, T. D., \& Campbell D. F. J. (2012). The quintuple helix innovation model: global warning as a challenge and driver for innovation. Journal of Innovation and Entrepreneurship, (1(1)), 1-12. doi: $10.1186 / 2192-5372-1-2$

9. Rumyantseva, E. E. (2005). Novaya ekonomicheskaya entsiklopediya. Moscow: INFRA-M.

10. Mochernyi, S. V. (Ed.). (2002). Ekonomichna entsyklopediia (Vol. III). Kyiv: Vydavnychyi tsentr «Akademiia».

11. Mochernyi, S. V. (Ed.). (2000). Ekonomichna entsyklopediia (Vol. II). Kyiv: Vydavnychyi tsentr «Akademiia».

12. Mochernyi, S. V. (Ed.). (2000). Ekonomichna entsyklopediia (Vol. I). Kyiv: Vydavnychyi tsentr «Akademiia». 13. Politolohiia. Zmist katehorii «polityka». Retrieved August 7, 2020, from https://pidru4niki.com/1056112736310/politologiya/scho_take_politika

14. Ofitsiinyi sait Derzhavnoi sluzhby statystyky Ukrainy. Retrieved August 7, 2020, from http://www.ukrstat.gov.ua/

15. Verner, I. Ye. (Ed.). (2019). Statystychnyi shchorichnyk Ukrainy za 2018 rik. Kyiv: Derzhavna sluzhba statystyky Ukrainy.

16. Prokopenko, O. M. (Ed.). (2019). Dovkillia Ukrainy za 2018 rik: statystychnyi zbirnyk. Kyiv: Derzhavna sluzhba statystyky Ukrainy.

17. Kostiuk, U. Z. (2015). Finansuvannia pryrodookhoronnoi diialnosti v Ukraini: suchasnyi stan ta shliakhy pokrashchennia. Innovatsiina ekonomika, (1), 181-186.

Received 11 August 2020

Approved 25 August 2020

Available in Internet 15.10.2020

Цитування згідно ДСТУ 8302:2015

Нікішина О.В. Теоретико-методичні положення щодо комплексної оцінки домінант інвестиційно-інноваційної політики природокористування України // Економіка харчової промисловості. 2020. Т.12, вип. 3. С. 66-80. doi: 10.15673/fie.v12i3.1818

Cite as APA style citation

Nikishyna, O. (2020). Theoretical and methodological provisions for a comprehensive assessment of dominants of investment and innovative policy of nature management of Ukraine. Food Industry Economics, 12(3), 66-80. doi: 10.15673/fie.v12i3.1818 